Corregpondencr.-It is the custom of the Officers of the State Historical Society at once to answer all letters requiring acknowledgement. They preserve, also, files of letters received. From these, the following, as only a part of those, which they hope to publish, are inserted, as connected with the history of current events, and so embraced in the design of this publication.

\title{
LETTER OF U. S. ATTORNEY GENERAL BATES.
}

\section{Washington, D. C., Attorney General's Office, ? July, 19, 1863 . $\}$}

Sam. J. Kirlewood, Esquire,

\section{President State Historical Society, Iowa City:}

SIR-I have received your letter of July 9 th, requesting me to furnish, for use of your Society, a "copy of each and all the published documents of [my] Department at [my] disposal."

Appreciating very highly, as I do, the excellent objects of such societies as yours, and their probable great usefulness in the future, I would take pleasure in eomplying with your wishes, if my office furnished any published matter worthy of a place among the preserved materials of history.

My office, considering the character of its duties, can hardly be called administrative. It deals little with the things and facts which constitute the current history of the country; but rather with the investigation of principles and the giving of opinions upon them. And, hence, there are very few documents published from my department; and, of that few, perhaps, none worthy of historic memory. Nevertheless, at the risk of being thought egotistic, I send you two pamphlets containing official opinions of mine, which have been pablished, because they were thought to concern great legal principles, and to touch the interest of a great many people :-1st, upon the power of the President to arrest and imprison individuals: $-2 \mathrm{~d}$, upon the power of public officers to create debts binding upon tho nation.

Very respectfully your ob't serv't,

ED. W. BATES. 
Copyright of Annals of Iowa is the property of State of Iowa, by \& through the State Historical Society of Iowa and its content may not be copied or emailed to multiple sites or posted to a listserv without the copyright holder's express written permission. However, users may print, download, or email articles for individual use. 